\title{
MAKING MISCHIEF: DAVID HARE AND THE CELEBRITY PLAYWRIGHT'S POLITICAL PERSONA
}

\author{
SANDRA MAYER
}

\begin{abstract}
This article examines the fashioning of the authorial persona of British playwright, screenwriter, and director David Hare through autobiographically inflected extra-theatrical interventions. Both exploratory and explanatory companion pieces that frame his artistic work, Hare's lectures, essays, and memoir capture and stage the field migrations between art and activism that lie at the heart of his public profile as a politically engaged celebrity playwright and astute social commentator. It will be shown how Hare exploits the generic properties of nonfictional life-writing formats that raise, and ostensibly meet, audience expectations of sincerity and authenticity and therefore become ideal vehicles for Hare's 'autobiomyth' of the prophetic writer-propagandist who strives to appeal to the moral conscience of his readership. Hare's conception of the authorial persona is informed by a Romantic tradition of strong authorship that is intimately connected with truth-telling discourses and that relies on the author's combined identities of artist and politically engaged commentator. This contribution argues that Hare's proclivity for non-fictional life-writing formats ties in with a sense of discomfort about his position as a playwright between establishment recognition and selfdeclared radicalism.
\end{abstract}

\section{KEY WORDS}

Literary Celebrity; Theatre; Politics; Life Writing; Lecture; Memoir

\section{INTRODUCTION}

The Harry Ransom Center at the University of Texas holds one of the most extensive performing arts collections in the world, including the papers of British playwright, screenwriter, and director David Hare (b. 1947), which make up over sixty boxes of typescript drafts of his stage and screen plays, production notes, rehearsal scripts, reviews, as well as personal notes and correspondence, covering his entire career from the late 1960s. Picking their way through the mundane and everyday in this personal archive, readers will come across a letter by broadcaster Melvyn Bragg, dated 13 June 1998. Bragg's message, scribbled on The South Bank Show letterhead, is a brisk and poignant response to Hare's knighthood, conferred as part of the Queen's 1998 Birthday Honours in recognition of his services to British theatre: "Dear David, Congratulations! Now where do you go? All the best, Melvyn" (Bragg 1998). For all its simplicity, Bragg's note carries weighty implications for the authorial profile and self-conception of someone newly endowed with the official badge of establishment recognition. 
Hare himself is clearly at pains to make light of his honours, owed to Tony Blair's 'New Labour' government, which, in its 'Third Way' social democracy and shift from left to centre, eerily mirrors the playwright's own ideological trajectory, taking him "from an alternative and Marxist-informed praxis to the mainstream of the political centre ground" (Deeney 2010, p. 429). In a note to actor Simon Callow, Hare is light-hearted:

Erik Satie was being driven mad by a friend who was boasting to him about all the awards he had turned down. Satie said: “Don't you realise the clever thing is not to turn down awards, it's to live the kind of life where they never offer you one in the first place?" In this I have failed. (Hare 1998)

What looks like self-ironic flippancy may well have been a strategy designed to pre-empt any niggling concerns about the apparent incongruousness of a relentless establishment critic turned decorated establishment figure; a disingenuous admission of defeat that resonates with Bragg's enquiry, mirroring Hare's often conflicted discomfort about his theatrical work and standing as a playwright. Indeed, Hare's knighthood appears to have tapped into, and augmented, what has been identified as a troubled phase in his career, coinciding with his "great champion and power-base" Richard Eyre's departure as artistic director of the National Theatre and his inability to complete the full-length play about Israel and Palestine he had been commissioned to write by the Royal Court Theatre's International Department (Luckhurst 2007, p. 58). Mary Luckhurst is among the scholars who believe that Hare's artistic crisis is firmly rooted in an anxiety about the socio-political relevance of his work in an increasingly fragmented political landscape that no longer offers ideological certainties and straightforward choices between socialism and capitalism (Luckhurst 2007, pp. 57-58). Moreover, in the light of theatrical practitioners who, from the 1990s onwards, have found innovative ways of engaging with the wider ramifications of identity politics and subscribed to a more inclusive definition of political theatre, Hare's aesthetic impasse can be attributed to "his profound sense of unease that theatrical realism and traditional purveyors of it like himself might indeed be redundant" (Luckhurst 2007, p. 57).

What at times seems close to a lapse of faith in his political theatre ultimately expresses itself in a curious vacillation between 'the roles of 'outsider' and 'insider', both the 'enemy' and the 'guardian' of the dominant culture and ideology" (Deeney 2010, p. 433). When South Downs, his autobiographical play about his time as a scholarship boy at Lancing College, opened in 2012 in the London West End in a double bill with Terence Rattigan's The Browning Version of 1948, Hare came close to acknowledging a dilemma more keenly felt than he has cared to admit:

T S Eliot, the most conservative of cultural critics, said that you can only add to a tradition by changing it. But at some point, you do actually fall into that tradition, don't you? If you're 64, as I am, you're part of it. So you can put a play on with one of Rattigan's and see the connection, whereas once you would have seen only the difference. (Qtd in Coveney 2012)

This ambivalence about his own career trajectory, from the leftist theatrical fringe of the 1970s to his status as canonical playwright whose success has been closely linked to the established, male-dominated institutions of the theatrical mainstream and their key stakeholders, ${ }^{i}$ most prominently suffuses Hare's autobiographically inflected extra-theatrical interventions. It is through them that he stages the persona of the truth-telling political playwright and fierce social and cultural critic who appears to speak from an outsider position in response to the need to find new relevance in a swiftly transforming political and theatrical landscape with which he has increasingly felt out of joint. As genres of self-exploration and self-justification, lecture and memoir both capture, and serve as vehicles for, the fluent cross-field migrations between the 
spheres of literature and politics that have been a vital element in the fashioning of Hare's public profile as a celebrity playwright. This article explores the construction of Hare's politically engaged authorial persona through the specific properties of non-fictional life-writing formats, whose 'truth capital' not only ties in with the truth-telling claims of his political drama but appeals to the playwright's authorial self-conception, heavily indebted, as it is, to the Romantic tradition of the author as rebellious and enlightened poeta vates. Hare's case demonstrates how a renewed focus on the personal and its illusion of authenticity can be employed as a strategy to address the vagaries of literary reputations over the course of a long career that spans both alternative and mainstream traditions and the need to reclaim authorial legitimacy in the fast-moving worlds of art and politics, where there is a serious threat of slipping "behind the dustcart instead of [being] in front of it" (Hare qtd in Kellaway 2018).

\section{Staging the Persona of the Political Playwright}

Over the course of his long career, David Hare has steadfastly cultivated and maintained a highprofile public persona as one of Britain's leading political playwrights, screenwriters, ${ }^{i i}$ and theatre and film directors, whose oeuvre also includes television plays, an opera libretto, theatrical collaborations, and stage adaptations of Brecht, Chekhov, Schnitzler, and Pirandello. Covering a range of dramatic subgenres, from well-made play, satire, and documentary and verbatim theatre to biodrama, pastiche, and what the dramatist himself identifies as 'stage poetry' (see Boon 2007, pp. 3-4), Hare's plays, with few exceptions, address topical issues and bear the recognisable hallmarks of English dramatic realism: they include, for instance, the media satire Pravda (1985), his collaboration with Howard Brenton; the National Theatre trilogy Racing Demon (1990), Murmuring Judges (1991), and The Absence of War (1993), which undertakes a painstaking dissection of the Church of England, the English legal system, and the Labour Party as three quintessentially English institutions in crisis; his self-performed, semiautobiographical stage monologue Via Dolorosa (1998), inspired by his Middle Eastern travels; the verbatim play Stuff Happens (2004) about the invasion of Iraq in 2003; The Power of Yes (2009), Hare's meditation on the financial crisis; and, most recently, I'm Not Running (2018), in which he addresses the conflict between traditional party politics and single-issue campaigning and tackles the thorny subject of female Labour leadership.

Frequently hailed, these days, by the media as "a grand old man of theatre" (Kellaway 2018), Hare started out his career in the late 1960s as part of a generation of socialist theatre practitioners operating within a network of alternative venues and touring companies. Following the West End success of his comedy Knuckle (1974), he quickly established himself as a figurehead who would lead "that generation, and its political and stylistic concerns, on to the stages of mainstream theatrical culture in the 1970s, when the epic 'State of the Nation' play in many ways set the agenda of theatrical innovation" (Boon 2007, p. 5). Hare's long-standing association with the "mainstream subsidized theatre sector" (Deeney 2010, p. 429) resulted in a prevalent media construction of him as the 'national playwright', and indeed no less than seventeen of his plays have to date been presented at the Royal National Theatre in London. Not surprisingly, perhaps, for someone who for many years served as its Associate Director, Hare's privileged position as the National Theatre's "'house dramatist'” (Deeney 2010, p. 431) facilitated his access to - and prominent exposure through - one of England's prime institutions of culture, enhancing his critical acclaim and public recognition and thus feeding straight back into the 'national playwright' myth. Royal Court realism (mainly that of a white, male variety) has made a claim to be dominant in English theatre, and this myth simultaneously builds upon and sustains one of the master narratives of English theatre historiography that fails to 
acknowledge the full scale and diversity of theatrical practice on the British Isles (see Luckhurst 2002).

Given Hare's well-known distaste for anti-realist aesthetics and their presumed detachment from historical and political realities, offering "not just a boring but an untrue view of life" (Hare 1991a, p. xiv), it is not without irony that he should have been the recipient of the 2011 PEN Pinter Prize. Awarded annually to a British, Irish, or Commonwealth writer who "casts an 'unflinching, unswerving' gaze upon the world, and shows a 'fierce intellectual determination ... to define the real truth of our lives and our societies'" (English PEN 2019), the prize is named in honour of Nobel laureate Harold Pinter, whose credentials as a political playwright Hare has always called into question. ${ }^{i i i}$ Hare has always firmly situated himself in the social realist tradition of the Royal Court writer's theatre that places the playwright at the centre of the theatrical process and invariably traces its contemporary pedigree back to John Osborne and Harley Granville-Barker (see Hare 2015a, p. 156). It is a tradition that has struggled to accommodate the political dimension of Pinter's work, and yet, Hare's PEN Pinter award, received, according to prize judge Michael Billington, for "address[ing] the big public issues over the past four decades with great rigour and wit" (qtd in Flood 2011), suggested he was an uncompromising cultural commentator uttering uncomfortable truths both on and off the theatre stage. It was a recognition in keeping with Hare's long history of border-crossings between the fields of art and politics, but one that both confirmed and, paradoxically, undermined his proudly flaunted non-conformism, reinforcing his familiar quandary: how can you be both outsider and insider, the leftist 'people's playwright' and part of the cultural establishment at the same time?

The way in which mainstream acceptance and establishment recognition complexly, and often uncomfortably, intersect with Hare's over-stated political radicalism and its perception by theatre practitioners and the critical profession crucially informs the construction of his public persona as political playwright and commentator. In the wake of his knighthood and in what could be interpreted as an instinctive response to Bragg's taunt, Hare has doubled up his efforts performing that persona. When asked, in an interview for the Guardian in 2011, whether in accepting those honours he had compromised his "radical credentials", Hare became defensive:

"It was an honour for which I didn't have to wait for someone to open an envelope and announce I'd won. They just gave it to you. To anyone who criticises me for it, I can say, 'Has my work declined or become less radical since?' My own view is no. I have written some of my most radical work ... since." (Qtd in Jeffries 2011)

Hare does not elaborate on what exactly "radical" means in the context of his work, but it is clear that he is at pains to stress its trailblazing vision and political edge even if the days are long gone when (revolutionary) socialism seemed a viable means of societal transformation. In what could be seen as an anxious move to fend off charges of establishment co-option, Hare steadfastly strives to maintain the image of the polarising playwright who has always subscribed to a "sound working principle" of 'making mischief', as he declares in a 1982 essay on public broadcasting and institutional censorship (Hare 1991b, p. 105). Priding himself on his adversarial thinking, which, in Hare's view, sets him apart from a somewhat bloodless generation of younger playwrights, thus forms an essential component of his self-canonisation strategy, aimed at reifying his status as one of the key figures of contemporary English drama.

Over the last forty years, Hare has increasingly stepped outside the dramatic medium and engaged in public lecturing, journalism, criticism, and autobiographical writing to communicate his views on topics as varied as the relationship of theatre and politics; the ethical function of political drama in a corrupt political world; the financial crisis and the effects of 
austerity; the collapse of traditional party politics; or, most recently, the disastrous consequences of Brexit. ${ }^{\text {iv }}$ Such extra-theatrical performances of the authorial self are in many ways symptomatic of a heavily commodified literary culture that is built around the celebrity capital of the media-savvy star author, whose heightened degree of public visibility results from repeated (re)presentations through a diverse range of media (Driessens 2013a, p. 552). As the author has successfully weathered poststructuralist opprobrium, and negotiated the literary sphere as a public intellectual, literature becomes a "lively and complex negotiation of text, author, reader and society" (Heynders 2016, p. 20) that no longer recognises a clear-cut demarcation line between poetics and politics. Hare's public talks, essays, and prefaces to his plays have been collected in two volumes, Writing Left-Handed (1991) and Obedience, Struggle \& Revolt (2005). Together with his published diary, Acting Up (1999), and his 2015 memoir The Blue Touch Paper, they map out the migration processes across different social fields that characterise the formation of celebrity persona. Media sociologist Olivier Driessens identifies migration as a "twofold process that captures the mobility and convertibility of celebrity" as well-known public figures like Hare "use both their relative autonomy as public personality and their celebrity status to develop other professional activities either within their original field or to penetrate other social fields" (2013b, p. 648). The four books, all published by Faber \& Faber, point towards Hare's multiple professional identities of playwright, screenwriter, stage and screen director, public lecturer, essayist, and general 'man of letters', all of which are designed to promote the persona of the contrarian, which, perhaps most obviously, is paratextually produced by the works' titles.

\section{HARE's “BaCkground MuRMuring”: MANAGing the Authorial Persona THROUGH THE MEDIUM OF THE LECTURE}

Testimony to his dynamic movements between art and action, Hare's non-fiction forms part of a public intervention which, on the one hand, frames or 'decorates' his work for stage and screen "with a kind of commentary": a "background murmuring", as Hare calls it, that helps him probe and sharpen his thoughts and ideas (2005a, p. 1). On the other hand, such ventures outside the literary medium to "take some kind of aerial view" also feature prominently in Hare's conception of the persona of the political writer as someone "who is likely to have an analysis as well as a view" (2005a, pp. 2, 1). While in the introduction to Writing Left-Handed, his first collection of lectures and essays, he still presents himself as ill-attuned to the activity of writing and delivering prose (Hare 1991a, p. ix), he has, in the meantime, clearly become a convert to the merits of the non-literary as exploratory and, more to the point, explanatory companion discourse to his artistic work. For Hare, the perceived limitations of the latter engender a keenly felt predicament that lays bare the complications of aligning the personas of artist and propagandist, both of which function as "fictive public identit[ies] drawn from elements of one's individuality but designed for public use" (Marshall \& Henderson 2016, pp. 13-14). As Hare explains in a 2004 lecture,

My creative self - the person inside me who would slowly go on to write twenty-two plays - was me and yet subtly not me. And, because of my companion's separate identity, an urgent dilemma would soon emerge. My desire was to use the theatre to argue for political change, and, at the start, to no other end. But early on it became obvious that the demands of what you would wish to accomplish politically cannot be so easily reconciled with what is artistically possible. (2005b, p. 22)

Among the genres that complement the political impetus of theatre, it is the lecture format that holds a particular attraction for Hare, not because it fundamentally differs from, but because, in 
his understanding, it closely resembles the architecture of a play, which emerges from a dialectic between what happens on the stage and what the audience makes of it. Writing in the introduction to his second volume of published lectures, Obedience, Struggle \& Revolt, Hare suggests that "[l]ectures and plays are alike in relying for their true vitality on the richness of the interaction between the performance itself and the thoughts and feelings created by the unspoken reaction in the room," only to add: "It is as if - hey! the better the speaker, the deeper the response" (2005a, p. 5).

Indeed, taking a closer look at Hare's frequent appearances on the international lecture circuit, it is apparent that they involve a considerable degree of performative self-projection and playing to the audience, which, from the early 1980s, he has increasingly found at elite institutions all over the world. Invitations to speak at top-ranking universities, prestigious literature and theatre festivals, the Royal Society of Literature, or at English PEN International Writer's Day simultaneously attest to, and further consolidate, his establishment status, which Hare often responds to by castigating those very same institutions that provide a platform to the playwright's truth-telling voice. When Hare gave a lecture at the University of Oxford in March 2016, it was not only another poignant reminder of the political edge that has always lined his performances of the authorial self; it also highlighted his tendency to adopt a strategy of 'attack from within', following his line of argument that "the best place to be radical [is] at the centre" (Hare 2015a, p. 256), where the rebellious playwright's voice can be heard by broad and diverse audience segments. Offering "A Playwright's View of Dismal Conservatism," as the lecture's title promised, Hare delivered a scathing invective against Thatcherism and its aftermath: the invariably Oxford-educated Tory (and Labour) key players responsible for the invasion of Iraq, the refugee crisis, the global financial crash, and austerity politics. The audience was left under no illusions about the general drift of Hare's message when he opened his address with what was designed as a running joke: "Occasionally, since the 1950s, whenever prime ministers have shown either unusual stupidity or unusual ignorance and I have asked the question 'Where on earth was he or she educated?' the answer has invariably been 'Oxford'” (Hare 2016, p. 1). Sustained throughout the lecture whenever some high-powered but hopelessly inept political figure was invoked, Hare's Oxford-bashing was a performance meant to antagonise his local audience (the greater part of whom, it is reasonable to assume, could not have agreed more) in a transparent bid of managing the persona of the leftist 'people's playwright'.

To all appearances, David Hare fully recognises the powerful impact of uninterrupted, unmediated utterance as a direct mode of self-presentation that relies, paradoxically, on the performative production of authenticity, turning the speaker/writer into a "clear eyed" observer (Hare 2005c, p. 95), a plain-spoken commentator and, at the same time, a theatrical performer. As John Lahr notes in his unflattering review of Writing Left-Handed, Hare's essays are less a serious commentary on the state of the arts and the contemporary political situation than a personal vanity project that serves the playwright's self-fashioning; they "don't so much illuminate the political stage as stage himself politically" (1991, n.p.). Lahr's severe appraisal ties in with Hare's own reluctant admission in the foreword to that volume that "it is hard for a playwright not to think of prose as an extended dramatic monologue, sometimes, I'm afraid, for a semi-fictional character" (1991a, p. xv); in his embrace of the lecture format, he takes full advantage of its theatrical potential and creates his own one-person show through which he moulds, performs, and manages the authorial persona of the politically engaged playwright and social commentator.

Chris Megson and Dan Rebellato have offered a compelling analysis of Hare's affinity for the lecture and other non-fictional formats and demonstrated how this preference relates to the aesthetics of his dramatic work and theatrical practice, which has relied on a "long-standing 
commitment to the pure, transparent and direct communication of subject matter in performance" (2007, p. 236). Both Hare's dramatic work and metadiscourse on the function and purpose of theatre reveal "a remarkable and doggedly persistent vision of theatre's potential capacity to deliver unmediated expression of content in a way that elides or even transcends the artifices that conventionally suture dramatic writing, authorial style and stage aesthetics" (2007, p. 238). His distrust in the artifice, false rhetoric, and mediation of theatrical representation in the late 1990s and 2000s culminated in his intermittent embrace of (semiJverbatim and documentary theatre. Starting with his self-performed monologue Via Dolorosa (1998), there has also been a move towards an at least partial conflation of author, performer, and subject, embedded in a discourse of authenticity and truthfulness. Hare's The Power of Yes (2009), for instance, features a fictionalised version of Hare, thinly disguised as the "Author", who tries to get to the root of the financial crisis. Based on Hare's conversations with bankers, investors, journalists, and academics, it fetishises the author's "inquisitorial persona" (Billington 2009), signalled, with little subtlety, by the play's subtitle: "A Dramatist Seeks to Understand the Financial Crisis".v

As Hare's "preferred mode of public address both on and off stage", the lecture enables Hare to navigate the vast territory between the poles of dispassionate dissection and provocative polemics, moving "from exposition to excoriation in equal measure" (Megson \& Rebellato 2007, pp. 236, 241). More importantly, however, when it comes to the negotiation of the public persona of the author, it provides him with a "form of direct address to an audience and a mode of self-presentation that entirely dispenses with actorly interposition in the communication of content" (2007, p. 238). There might be a fundamental scepticism on Hare's part towards the potentially distorting effects of theatrical mediation processes, such as dramaturgy, acting performance, and aesthetic experiment; yet, in the case of his extratheatrical interventions, they get eliminated only to be replaced by a strong authorial interposition as a mediating agency that creates a similar "barrier of artifice" (2007, p. 246) between the audience and the communicated content in the shape of the playwright-activist persona. This persona emerges from a performative self-presentation that rests, most crucially, on the unchallenged authority of the inspired artist-creator who is supposedly qualified not only to deliver acute assessments of larger socio-political and ethical questions but to provide guidance and instruction on the interpretation of their work.

\section{A PORTRAIT OF THE ARTIST AS Young GeNIUS: AUTHORIAL 'AUTOBIOMYTHS' IN HARE's MEMOIR THE BLUE TOUCH PAPER}

A firm belief in the absolutism of authorial meaning-making underlies Hare's repeated attacks on the critical profession and director's theatre. "[W]ith all its naff ideas and its opportunities for largely arbitrary pieces of self-advertisement", the latter, in his opinion, stubbornly fails to comprehend the play "as something which work[s] in an intended area of meaning" (Hare 2005c, p. 106). As he insists in his 1997 lecture "A Defence of the New", a play is "not just a toy with which a director might mess around at will in order to advertise for further employment". In his self-understanding as a political playwright Hare thus subscribes to a primal myth of authorship in which those fabled 'intended areas of meaning' might perhaps not simply be reduced to, but are sharply staked out by, the omnipotent "author's conception" (Hare 2005c, p. 106). In fact, the title of his talk, full of nostalgia for the good old days of political playwriting and their uncomplicated ideological militancy, invokes an illustrious historical progenitor that powerfully serves Hare's self-mythologising of the artist as rebel and visionary: Percy Bysshe Shelley's 1821 essay “A Defence of Poetry”, his defiant celebration of creative power which ends 
on one of the most programmatic lines of authorial self-affirmation - "Poets are the unacknowledged legislators of the World" (Shelley 2000, p. 802).

Indeed, the authorial persona that materialises through what is clearly more than the subtle "background murmuring" Hare professes to engage in, feeds on a Romantic conception of strong authorship that casts the author in the role of the enlightened poeta vates - a prophetic (but generally misunderstood and underrated) moral authority who strives to appeal to the political and social conscience of their readership. In this theory of authorship, the author's cultural capital and authority are intimately connected with truth-telling discourses that render the author's combined identities of artist and cultural critic a veritable default mode. In a recent interview for the Guardian, Hare suggests as much when he comments on what sets apart writers and politicians in the public perception: "I'm a writer and it's assumed I'm speaking the truth" (qtd in Kellaway 2018). In what might be a belated reaction to his traumatic encounter with Leavisite literary criticism at Cambridge, ${ }^{\text {vi }}$ he thus firmly situates himself within a Romantic tradition that fetishises the author as expressive genius and divinely gifted agent of metaphysical revelation when he outlines his vision of the author's universal role: "whether they intend to or not, ... in free as in totalitarian societies", writers "remind their audience of an alternative and perhaps more profound way of looking at experience than would otherwise be available" (Hare 1991a, p. xii). This white, colonial myth of (usually male) authors as unyielding truth seekers and tellers is an important factor that legitimises their forays into political commentary, which reminds us, as Nahuel Ribke has shown in his 'genre approach' to celebrity politics, that notable public figures come with a whole set of meanings, anchored in, and constructed through, their original or primary field(s) of action. These meanings, Ribke argues, are "hierarchically structured according to the prestige of the genres with which they are associated within the fields of cultural production and consumption" and thus vitally affect someone's success in converting their celebrity capital into political influence (2015, p. 172). The status writers occupy in the cultural imagination and its framework of literary values and traditions, as well as the media they have access to in the fields of cultural production, trigger specific audience expectations that can be instrumental to easing their passage into the sphere of political commentary.

Genre and the prestige it carries not only enable and facilitate the literary/political field migrations that lie at the heart of David Hare's authorial persona, but they also intimately affect the way in which they are staged and articulated. In his proclivity for the lecture, the essay, and, more recently, the memoir, he recognises and exploits their value as direct and controlled selffashioning platforms but also heavily relies on the cultural expectations raised by these genres' potential of "truth capital" (Gonzalez 2018, p. 298). As Hare concedes, his lectures and essays are suffused by a marked "autobiographical thread" (1991a, p. ix) and therefore - just like his published diary or memoir - enable the audience to enter what Philippe Lejeune has famously called the 'autobiographical pact': a social and literary convention through which the reader implicitly accepts the purported truthfulness and authenticity of autobiographical utterance that resides in the unity of a text's author, narrator, and subject (Lejeune 2016, pp. 37, 43). In the light of such a 'contract', which is established by a host of paratextual and textual clues, autobiographical narrative will invariably be assessed in terms of the truth claims it makes; and yet, autobiographical truth is necessarily a "polyphonic site of indeterminacy" as it comes into being through "intersubjective exchange" between author-narrator and audience in a joint meaning-making project (Smith \& Watson 2010, p. 16).vii Uneasily positioned between the factual and the fictional and intimately concerned with notions of the self, identity, subjectivity, and agency, autobiographical telling seeks to stage and negotiate public and private versions of the self through strategies of narrativisation, selection, interpretation, and relationality; always 
a performative display of identity, and therefore inherently political, it strives to impose patterns of coherence and teleology onto the messiness and inconsistencies of an individual life and whip it into a seemingly pre-determined shape. Promising the insight and revelation of a 'true story', it also expects audiences to be "open to the complexities of truth" (Marcus 2018, p. $4)$.

An analysis of David Hare's performances of authorial identity through autobiographical narrative and commentary could usefully draw on Michael Benton's concept of "biomythography". Developed in the context of literary biography, which often approaches its subjects with a wish to illuminate the origins and inscrutable workings of the creative impulse and to untangle the knotted and myth-encrusted relationship of the author's life and work, the term "subverts any concept of life-writing based on a simplistic account of supposed 'facts'. It acknowledges the importance of context and historicity; but, more than that, it reflects the ways in which what we take as facts are subject to narrative representation and cultural mutability" (Benton 2009, p. 63). The concept hence does justice to the processes of myth-making and fictionalisation and the multiple symbolic and subjective truths that underlie "versions of the self as expressed in different contexts, driven by different motives, for a variety of purposes" especially in genres of life writing, where myth regularly steps in to battle the "anxiety of uncertainty" (Benton 2009, pp. 64, 66) produced by gaps in the historical record or the ambiguities and contradictions that mark the trajectory of individual lives.

What Benton observes with regard to literary biography also counts for literary autobiography and memoir, which, as in Hare's case, often perpetuate the familiar cultural myth of the writer as rebel figure who offers an acutely perceptive critique of society, its norms and institutional frameworks, and the dominant zeitgeist. In his 2015 memoir The Blue Touch Paper, based on a series of recorded conversations with journalist Amy Raphael, Hare rehearses his familiar repertoire of 'autobiomyths', most of them offering variations on a 'Portrait of the Artist as Inspired Young Genius' whose remarkable sensibilities - if not his hypersensitivity - render him an astute social and cultural commentator. Covering the years from 1947 to 1979, the memoir charts Hare's path from an emotionally starved lower middle-class childhood on the Sussex coast on to public school and Cambridge university education and, from there, swiftly up the "food chain of British theater" (Brown 2015). Its narrative, broadly chronological though episodic and at times digressive, focuses on the self-making of the professional playwright, whose success story firmly rests on the heroic achievements of the post-war welfare state and whose unwavering commitment to theatre as an agent of political change ostensibly emerged from a gnawing sense that the ideals of social democracy were being betrayed.

Blending salacious gossip and strategic name-dropping with anecdote and confession, The Blue Touch Paper bears all the hallmarks that define memoir as a notoriously unstable genre situated between the public and the private, the factual and the imagined, historical documentation and literary art. As Julie Rak argues, "it is both finished and unfinished, unofficial and official, a collection of reminiscences of an occasional character, but also a record of historic events where the events, or the person who records them, is emphasized" (2004, p. 495). Not surprisingly, given his 'autobiomythographical' project, Hare most prominently draws on the generic templates of the bildungsroman and coming-of-age narrative which chronicle the formation of the subject's self and frame it in terms of growth, becoming, and agentic selfdetermination. As it "seeks to tell how a young man became a dramatist, and to describe the cost and effect of that decision", Hare's account of his "apprenticeship" (2015a, pp. xv-xvi) feeds on, and perpetuates, a self-affirming artist-as-hero myth that accommodates both selfaggrandisement and self-deprecation, hyper-confidence and crippling insecurity. His story of becoming is clearly aimed at corroborating his significance as a political playwright and central 
voice in contemporary English drama, and there is a curious reticence to play up his successes as a screenwriter and director. While Hare has always felt at home in a text-based tradition of English writer's theatre, focused on the "adulation of the playwright ... as a sage for the times" (Kershaw 2004a, p. 301) that bolsters the myth of the omnipotent auteur as the source of all meaning, there has been a marked scepticism towards the media of film and television (see Hare 2002). There, the writer's (or director's) contribution is filtered through a whole host of agents and stakeholders and can result in the diminution of the strong authorial persona Hare has been keen to perform.

Seamlessly switching in tone from light-hearted to caustic, self-ironic to pretentious, and consistent only in its round condemnation of politicians and critics of all shapes and sizes, the memoir is conspicuously marked by what one critic described as a "combination of deliberate ambivalence and more inadvertent contradictions" (Walton 2015). What often expresses itself through "boastful modesty" (Jury 2015), a curious mix of boisterous and humble, and a noticeable indecision between self-glorification and self-demolition, reveals Hare's underlying sense of unease about trying to reconcile his bourgeois status with the rebel, stuck in between centre-ground, middle-class respectability and a rhetorical harking back to old socialism. As he writes about his supposedly conflicted class-consciousness, his perpetual (and often physically incapacitating) fear of failure, his long-standing professional and romantic involvement with Kate Nelligan, which "made the pair of us both insufferable for years" (2015a, p. 203), the breakup of his marriage and the guilt of leaving a family with three young children, Hare's soul-baring narration occasionally teeters into self-hatred. As Mark Lawson observes in his review of The Blue Touch Paper, "At times, a reader may feel that the book should have been called Hare Shirt" (Lawson 2015). The way in which Hare peppers his account with self-flagellating confession could be interpreted as an attempt to elicit sympathy for the failing hero forced to do penance for his hubris, which ties in with a desire for social levelling that underlies the cultural fascination with celebrity life narratives. At the same time, chipping away at his own pedestal lends gravitas to the myth of the author as clear-sighted genius, whose unique gift for penetrating analysis comes from a torturous sense of uncertainty that leads to rigorous selfexamination. Hare's comment on the memoir's reception in a US radio interview suggests as much:

A lot of people have said this about the book - that I seem to be very tough on myself. But you know, I'm a writer. And an awful lot of writers are driven by self-hatred. My ability to see what's going on in a room or analyze what's going on inside a person comes from my own doubts about what's going on inside myself. (Hare 2015b)

As self-hatred is intricately bound up with Hare's project of self-mythologisation, the strategies of 'new memoir' might have allowed for innovative and aesthetically challenging modes of engaging with the narrator-subject's ambivalence and frequent self-contradictions. Often characterised by formal experimentation, including novelistic techniques, a fragmented and episodic structure, experimental syntheses of word and image, or playful subversions of 'authenticity' markers, such as footnotes and indices, 'new memoirs' - as opposed to traditional memoirs - "are fundamentally more obtrusively aware of the mediated nature of life, the unwieldiness of experience, the fallibility of memory, and the artifice of textual transformation" (Madden 2014, p. 223). Rather than questioning "the direct and transparent relation among act and memory and text" (2014, p. 229) and traversing the slippery terrain of 'objective' historical record and personal testimony with playful self-reflexivity, Hare aims to achieve an effect of historical accuracy and authenticity. He presents himself as a reliable narrator by interspersing his recollections with primary material that serves the purpose of external validation and endorsement: letters and examples of "exceptionally perceptive" reviews (2015a, p. 341), 
reproduced either in full or in excerpts, by eminent contemporaries and long-standing associates such as Peggy Ramsay, Tom Stoppard, or Philip Roth.

It is here, in the insistence on veracity and referentiality, and, perhaps most conspicuously, where the personal intersects with lengthy authoritative commentary on larger political and socio-cultural transformations, that Hare's memoir invariably assumes the guise of the author's signature format of expression - the lecture. Stirrings of self-exploration and analysis often get nipped in the bud by a potent mix of social history, lament, and polemic; not surprisingly so, given the memoir's express aim to "reclaim the 1970s from the image which politicians of one fierce bent have successfully imposed with the help of largely compliant historians", as Hare stressed in his 2016 Oxford lecture (p. 2). Hare's great grievance is the demise of the British welfare state, whose death knell came with the cataclysmic caesura of Margaret Thatcher's election victory in 1979 and its fateful long-term consequences:

Like so many socialists of my age, I had insufficiently appreciated the values of the welfare state because all I had been able to see were its shortcomings. Many of us in our nightmares had imagined violence, the seizure of the country at the end of a gun by plutocrats or the military. But for those of us who were committed to believing in the essential wisdom of electorates, the idea of the country agreeing to hand itself back to the laissez-faire barbarism of the years before the war was unimaginable ... Up till now, for those of us born in 1947, the direction of travel, however erratic, had been towards social justice and equality. From this point on, it would be a retreat. (Hare 2015a, p. 332)

Linking up public with private watershed moments, David Hare's memoir thus situates itself in a category of self-writings that seek to relate personal experience to the momentous impact of historical events and external forces. The reader encounters an "autobiographical 'I' [who] becomes a traveller through, and at times a guide to, wider cultural and historical forces, as the individual life-course intersects with, and is shaped by, collective events and experiences" (Marcus 2018, p. 79). And who could provide more sagacious guidance on the contemporary condition than the autobiographical 'I' of the author - the divisive, hypersensitive seer and speaker of uncomfortable truths acting as society's much-needed corrective?

\section{CONCLUSION}

In its capacity to construct and uphold a successful fallacy of authenticity and intimate connection between narrator-subject and audience, autobiographical discourse must necessarily hold an irresistible appeal for someone who seeks to build his authorial persona on a conflation of art and action, aesthetics and ethics, intra- and extra-theatrical worlds. Memoir in particular, as a site for negotiating the subject's position in the cultural imaginary and the relationship between their personal and professional identities, becomes a powerful vehicle for the autobiomyth of the trailblazing, politically engaged author, who is aware of his social responsibility and, guided by principle and personal integrity, is "always happiest when [he] ha[s] a cause" (Hare 2015a, p. 174). At the same time, the genre makes room for the staging of ambivalence, contradictions, and inconsistencies, as the image of the failing public figure, confessing their shortcomings and weaknesses and revealing themselves to be an ordinary, imperfect human being, constitutes a widely accepted key feature of seemingly authentic selfpresentation, inviting relatability and audience sympathy. As Julie Rak observes in her analysis of the twenty-first-century 'memoir boom', "Memoir is a way of thinking and perhaps even of being public, as it remains a way to construct, package, and market identity so that others will want to buy it. Therefore, it is subject to generic 'rules'” (2013, p. 7). These generic specificities guide audiences in their consumption and interpretation of a cultural product as they raise 
expectations that work through repetition and, eventually, the pleasurable recognition of the familiar; genres thus "produce a type of grammar that does far more than merely organize objects. It provides a way to say what constitutes a 'legitimate' or recognizable object in a system, and what does not" (2013, p. 26). Ultimately, therefore, it is not so much about whether the 'truth content' of a narrative can be verified or discredited but to what extent it meets the audience's expectations of sincerity, authenticity, and revelation.

David Hare capitalises on the generic prestige and impact of non-fictional life-writing formats in his quest to build and sustain the persona of the prophetic writer-activist and "latterday 'man of letters' in the tradition of Bernard Shaw and John Osborne" (Megson \& Rebellato 2007, p. 236). He feels acutely, it seems, the eternal conundrum of the writer, torn between aesthetics and ethics, form and content, subversion and conformism; alternately driven to step outside the artistic medium to fulfil a cultural responsibility, and anxious that literary art should have deteriorated into a mere tool of political propaganda. Hare's response to this dilemma has been to engage in a cultural idealisation of the artist as genius allrounder who is equally at home in the spheres of literature and agitation, the fictional and the factual, the literary and the nonliterary - a move that may, in Hare's own case, have led to an artistic deadlock but that has fuelled his celebrity status as a playwright.

\section{FUNDING}

This work was supported by the Austrian Science Fund (FWF) [grant number T922-G30].

\section{ACKNOWLEDGEMENTS}

For permission to quote from material preserved in the David Hare Collection, I wish to acknowledge the Harry Ransom Center at the University of Texas at Austin; Casarotto Ramsay \& Associates Ltd on behalf of David Hare; Sheil Land Associates on behalf of Melvyn Bragg. I am grateful to Elizabeth L. Garver for helping me navigate the Harry Ransom Center's holdings of the David Hare Papers and making uncatalogued material available to me.

\section{END NOTES}

i A complex and diverse phenomenon, 'mainstream theatre' is generally taken to comprise "West End commercial theatre and commercial venues of the regional touring circuits, subsidised regional repertory theatres and other municipal theatres, and the national theatres (Royal National Theatre, Royal Shakespeare Company)" (Kershaw 2004b, p. 349).

ii David Hare's screenplays for television and feature films include Wetherby (dir. David Hare, 1985), The Hours (dir. Stephen Daldry, 2002), The Reader (dir. Stephen Daldry, 2008), Page Eight (dir. David Hare, 2011), Denial (dir. Mick Jackson, 2016), and Collateral (dir. S. J. Clarkson, 2018).

iii Commenting on Pinter's play The Caretaker (1960), Hare rejects the idea of a political agenda on Pinter's part, and, in the same breath, implies a categorical division between psychological and political drama that does not allow for porous boundaries: "The drama is psychological and between people in that room. (Harold now argues that his intentions were political; I don't believe him. ...) I could never write a play in which the engagement was purely psychological, because to me, who people are is affected by time and place and the nature of the society they live in" (Hare qtd in Boon 2003, p. 173). 
iv Referring to the outcome of the EU referendum and its aftermath as "the most depressing time in his life" (Wiegand 2017), Hare joined high-profile writers Abi Morgan, A.L. Kennedy, Meera Syal, and James Graham to participate in the Brexit Shorts campaign, a Guardian and Headlong theatre company co-production. Part of a series of online films addressing the causes and effects of the 2016 referendum, Hare's "Time to Leave" features Kristin Scott Thomas as a disillusioned leave voter one year on.

$v$ It is worth noting that Hare is not alone among his generation of male, leftist playwrights in his turn towards the self and the personal as a way of renegotiating his standing and the tenets of his political drama in a changed theatre landscape. In 2018, Hare's long-standing comrade-inarms, David Edgar, marked his $70^{\text {th }}$ birthday by putting on and performing his autobiographical one-man show Trying It On, a "mix of rigorous self-inquisition and exploration of the failed hopes and dreams of the 1960s" (Billington 2018).

vi In his memoir The Blue Touch Paper Hare recounts how it implanted in him a deep-seated aversion against "art which needs a framework of art theory to be understood" (2015a, p. 97).

vii This ties in with Hare's understanding of the theatrical experience as residing in the interaction of playwright, stage performance, and audience. In his first lecture, given at a theatre conference at King's College, Cambridge, in 1978, he famously argued that a play and its political impact come into being through a collaborative experience of exchange: "A play is not actors, a play is not a text; a play is what happens between the stage and the audience. ... So if a play is to be a weapon in the class struggle, then that weapon is not going to be the things you are saying; it is the interaction of what you are saying and what the audience is thinking. The play is in the air" (2005d, p. 118).

\section{WORKS CITED}

Benton, M. 2009, Literary Biography: An Introduction, Wiley-Blackwell, Chichester.

Billington, M. 2009, 'The Power of Yes', The Guardian, 6 October, retrieved 29 October 2019, $<$ https://www.theguardian.com/stage/2009/oct/07/power-of-yes-billington-review $\geq$

-2018, "The Haranguing of David Edgar - By His 20-year-old Self", The Guardian, 29 October, retrieved 30 October 2019, $<$ https://www.theguardian.com/stage/2018/oct/29/haranguing-david-edgar-trying-iton-royal-court>

Boon, R. 2003, About Hare: The Playwright and the Work, Faber \& Faber, London.

-2007, 'Introduction' in R. Boon (ed.), The Cambridge Companion to David Hare, Cambridge University Press, Cambridge, pp. 1-11.

Bragg, M. 1998, Autograph Letter Signed to David Hare, 13 June 1998, David Hare Collection, Third Acquisition (uncatalogued), Correspondence 1997-1998, Box 60, Harry Ransom Center, The University of Texas at Austin.

Brown, T. 2015, “"The Blue Touch Paper: A Memoir," by David Hare', The New York Times, 16 November, retrieved 5 May 2019, <https://www.nytimes.com/2015/11/22/books/review/the-blue-touch-paper-amemoir-by-david-hare.html>

Coveney, M. 2012, 'The Unhappiest Time of His Life: David Hare on Dramatising His School Days', The Independent, 20 April, retrieved 28 October 2019, $<$ https://www.independent.co.uk/arts-entertainment/theatre-dance/features/theunhappiest-time-of-his-life-david-hare-on-dramatising-his-school-days-7660994.html>

Deeney, J. 2010, 'David Hare and Political Playwriting: Between the Third Way and the Permanent Way' in M. Luckhurst (ed.), A Companion to Modern British and Irish Drama 1880-2005, Wiley Blackwell, Oxford, pp. 429-440. 
Driessens, O. 2013a, 'Celebrity Capital: Redefining Celebrity Using Field Theory', Theory and Society, vol. 42, no. 5, pp. 543-560.

-2013b, 'The Celebritization of Society and Culture: Understanding the Structural Dynamics of Celebrity Culture', International Journal of Cultural Studies, vol. 16, no. 6, pp. 641-657.

English PEN 2019, 'PEN Pinter Prize', English PEN, retrieved 10 July 2019, <https://www.englishpen.org/events/prizes/pen-pinter-prize/>

Flood, A. 2011, 'David Hare Wins PEN/Pinter Prize', The Guardian, 26 August, retrieved 10 July 2019, <https://www.theguardian.com/stage/2011/aug/26/david-hare-wins-penpinter-prize>

Gonzalez, M. 2018, 'Disappearing into the Front Page: The Case of Salman Rushdie and the Postmodern Memoir' in R. Bradford (ed.), A Companion to Literary Biography, WileyBlackwell, Oxford, pp. 291-307.

Hare, D. 1991a, 'Introduction' in D. Hare, Writing Left-Handed, Faber \& Faber, London, pp. ix-xv.

-1991b, 'Ah! Mischief: On Public Broadcasting' in D. Hare, Writing Left-Handed, Faber \& Faber, London, pp. 93-105.

-1998, copy of typed fax to Simon Callow, undated, David Hare Collection, Third Acquisition (uncatalogued), Correspondence 1997-1998, Box 60, Harry Ransom Center, The University of Texas at Austin.

-2002, 'Introduction' in D. Hare, Collected Screenplays 1, Faber \& Faber, London, pp. vii-xiii.

-2005a, 'Introduction' in D. Hare, Obedience, Struggle \& Revolt: Lectures on Theatre, Faber \& Faber, London, pp. 1-8.

-2005b, 'Obedience, Struggle \& Revolt' in D. Hare, Obedience, Struggle \& Revolt: Lectures on Theatre, Faber \& Faber, London, pp. 9-32.

-2005c, 'A Defence of the New' in D. Hare, Obedience, Struggle \& Revolt: Lectures on Theatre, Faber \& Faber, London, pp. 87-110.

-2015a, The Blue Touch Paper: A Memoir, Faber \& Faber, London.

-2015b, 'Author Interviews: Dramatist David Hare Says, Like Many Writers, He's Driven By Doubt', National Public Radio, 31 October, retrieved 6 May 2019, $<$ https://www.npr.org/2015/10/31/453155446/dramatist-david-hare-says-likemany-writers-hes-driven-by-doubt?t=1556171023562>

-2016, 'Putting the Clock Back: A Playwright's View of Dismal Conservatism', Richard Hillary Memorial Lecture, Blavatnik School of Government, University of Oxford, 3 March, pp. 112, retrieved 25 May 2019, <http://www.trinity.ox.ac.uk/wordpress/wpcontent/uploads/2016/03/David Hare Lecture PUTTING-THE-CLOCK-BACK.pdf>

Heynders, 0. 2016, Writers as Public Intellectuals: Literature, Celebrity, Democracy, Palgrave Macmillan, Basingstoke.

Jeffries, S. 2011, 'David Hare: "It's absurd, but I feel insecure"', The Guardian, 3 September, retrieved 30 May 2019, <https://www.theguardian.com/culture/2011/sep/03/davidhare-i-feel-insecure>

Jury, L. 2015, 'The Blue Touch Paper by David Hare, Book Review', The Independent, 5 September, retrieved 3 May 2019, < https://www.independent.co.uk/artsentertainment/books/reviews/the-blue-touch-paper-by-david-hare-book-review10484833.html>

Kellaway, K. 2018, 'State of Play: David Hare and James Graham Talk Drama and Politics', The Observer, 6 May, retrieved 9 May 2019, $<$ https://www.theguardian.com/stage/2018/may/06/david-hare-james-grahamdrama-politics-labour-party>

Kershaw, B. 2004a, 'British Theatre, 1940-2002: An Introduction' in B. Kershaw (ed.), The Cambridge History of British Theatre Vol. 3: Since 1895, Cambridge University Press, Cambridge, pp. 291-325.

-2004b, 'Alternative Theatres, 1946-2000' in B. Kershaw (ed.), The Cambridge History of British Theatre Vol. 3: Since 1895, Cambridge University Press, Cambridge, pp. 349-376. 
Lahr, J. 1991, 'Hare's Breadth', Vogue, May, David Hare Collection, Series V. Career and Personal, Reviews Writing Left-Handed, 1990-91, Box 33, folder 2, Harry Ransom Center, The University of Texas at Austin.

Lawson, M. 2015, 'II hated myself”: David Hare's Self-Flagellating Memoir', New Statesman, 12 September, retrieved 5 May 2019, <https://www.newstatesman.com/culture/books/2015/09/i-hated-myself-david-hares-self-flagellating-memoir>

Lejeune, P. 2016, 'The Autobiographical Pact' in R. A. Chansky \& E. Hipchen (eds), The Routledge Auto/Biography Studies Reader, Routledge, London \& New York, pp. 34-48.

Luckhurst, M. 2002, 'Contemporary English Theatre: Why Realism?' in M. Rubik \& E. MettingerSchartmann (eds), (Dis)Continuities: Trends and Traditions in Contemporary Theatre and Drama in English, WVT, Trier, pp. 73-84.

-2007, 'Harold Pinter and Poetic Politics' in R. D’Monté \& G. Saunders (eds), Cool Britannia? British Political Drama in the 1990s, Palgrave Macmillan, Basingstoke, pp. 56-68.

Madden, M. 2014, 'The "New Memoir"', in M. DiBattista \& E. O. Wittman (eds), The Cambridge Companion to Autobiography, Cambridge University Press, Cambridge, pp. 222-236.

Marcus, L. 2018, Autobiography: A Very Short Introduction, Oxford University Press, Oxford.

Marshall, P.D. \& Henderson, N. 2016, 'Political Persona 2016 - An Introduction', Persona Studies, vol. 2, no. 2, pp. 1-18.

Megson, C. \& Rebellato, D. 2007, “'Theatre and Anti-Theatre”: David Hare and Public Speaking' in R. Boon (ed.), The Cambridge Companion to David Hare, Cambridge University Press, Cambridge, pp. 236-249.

Rak, J. 2004, 'Are Memoirs Autobiography? A Consideration of Genre and Public Identity', Genre, vol. 37, pp. 483-504.

-2013, Boom! Manufacturing Memoir for the Popular Market, Wilfrid Laurier University Press, Waterloo, Ontario.

Ribke, N. 2015, A Genre Approach to Celebrity Politics: Global Patterns of Passage from Media to Politics, Palgrave Macmillan, Basingstoke.

Shelley, P.B. 2000, 'A Defence of Poetry' in M.H. Abrams et al (eds), The Norton Anthology of English Literature, vol. 2, $7^{\text {th }}$ ed., Norton \& Company, New York, pp. 790-802.

Smith, S. \& Watson, J. 2010, Reading Autobiography: A Guide for Interpreting Life Narratives, 2nd ed., University of Minnesota Press, Minneapolis.

Walton, J. 2015, 'The Blue Touch Paper by David Hare, Review: “A Vanished Era”', The Telegraph, 18 September, retrieved 3 May 2019, <https://www.telegraph.co.uk/books/what-toread/the-blue-touch-paper-david-hare-review/>

Wiegand, C. 2017, 'Leading Playwrights Create Brexit Dramas for the Guardian', The Guardian, 19 June, retrieved 10 May 2019, $<$ https://www.theguardian.com/stage/2017/jun/19/leading-playwrights-createbrexit-shorts-david-hare-abi-morgan> 